\title{
Efficacy Improvement of a Bioherbicidal Fungus Using a Formulation-Based Approach
}

\author{
Clyde D. Boyette ${ }^{1}$, Robert E. Hoagland ${ }^{2}$, Kenneth C. Stetina ${ }^{1}$ \\ ${ }^{1}$ USDA-ARS, Biological Control of Pests Research Unit, Stoneville, MS, USA \\ ${ }^{2}$ USDA-ARS, Crop Production Systems Research Unit, Stoneville, MS, USA \\ Email: *doug.boyette@ars.usda.gov
}

How to cite this paper: Boyette, C.D., Hoagland, R.E. and Stetina, K.C. (2016) Efficacy Improvement of a Bioherbicidal Fungus Using a Formulation-Based Approach. American Journal of Plant Sciences, 7, 2349-2358.

http://dx.doi.org/10.4236/ajps.2016.716206

Received: September 9, 2016

Accepted: November 25, 2016

Published: November 28, 2016

Copyright $\odot 2016$ by authors and Scientific Research Publishing Inc. This work is licensed under the Creative Commons Attribution International License (CC BY 4.0).

http://creativecommons.org/licenses/by/4.0/

\begin{abstract}
Greenhouse experiments were conducted to determine the effects of an invert (water-in-oil) emulsion (IE) on dew period duration and dew delay of Colletotrichum coccodes for biocontrol of the problematic weed, eastern black nightshade (Solanum ptycanthum). Dew periods of 4,8 , or $12 \mathrm{~h}$ provided $10 \%, 25 \%$, and $40 \%$ control of eastern black nightshade plants, respectively, when $C$. coccodes (Strain NRRL $15,547)$ spores were applied in water + Tween 80 surfactant 12 days after inoculation, but a minimum of $16 \mathrm{~h}$ of dew was required to achieve $~ 95 \%$ plant mortality. In contrast, at these same intervals of dew, 95\%, 100\% and 100\% mortality occurred, respectively, when fungal spores were formulated in the IE. Even in the absence of dew, $60 \%$ mortality and 70\% dry weight reductions of plants was achieved with the fungus/IE formulation Delaying dew by $2 \mathrm{~h}$ after inoculation did not significantly reduce weed control or plant dry weight reductions when plants were inoculated with the fungus either in the aqueous or in the IE formulation. However, when dew was delayed for 4,8 , or $12 \mathrm{~h}$, only $60 \%, 50 \%$, and $25 \%$ mortality, respectively, of plants receiving the aqueous spore treatment occurred. In contrast, $95 \%, 90 \%$, and $90 \%$ weed mortality occurred after the same dew delays of plants receiving the fungus/IE treatments. These results demonstrate that formulating C. coccodes spores in an invert emulsion greatly improves the bioherbicidal potential of this fungus. Furthermore, results suggest that this formulation may render pathogens previously rejected for development as bioherbicides due to restrictive dew requirements more efficacious for use in controlling their target weeds.
\end{abstract}

\section{Keywords}

Colletotrichum coccodes, Solanum ptycanthum, Bioherbicide, Invert Emulsion, Formulation 


\section{Introduction}

Strategies using plant pathogens as bioherbicides to manage weeds have been examined as demonstrated in several reviews [1]-[10]. In order to achieve greater predictability and acceptability, it is necessary to maximize the capability of a bioherbicidal pathogen to infect, kill, or reduce the competitiveness of the weed host. Many fungi, including most bioherbicidal fungi, have a requirement for free water, such as dew, for germination and infection to occur [7] [11] [12]. Increasing the infectivity (ability to infect host) of a bioherbicidal fungus in any given dew period, theoretically will increase the effectiveness of pathogen [13].

One strategy to reduce lengthy dew requirements of bioherbicidal fungi is the use of selected adjuvants including surfactants, stickers, humectants, and anti-evaporation agents [7] [9] [14]. Previous research in our laboratory and elsewhere has shown that invert (water-in-oil) emulsions and various vegetable oil-in-water emulsions provide a method to retard evaporation and trap water around fungal spores in the spray mixture, thereby decreasing the amount of additional free-moisture (dew) required for spore germination and infection [15]-[21]. We have previously reported greenhouse data that show a 1:1 (v/v) fungus/invert emulsion could reduce the dew period requirements for maximum weed infection and mortality of sicklepod [Senna obtusifolia (L.) H.S. Irwin \&_Barneby] with the fungus Colletotrichum gloeosporioides (Penz.) Penz. \& Sacc, from $16 \mathrm{~h}$ to $8 \mathrm{~h}$, and could also delay the need for free moisture for $>48 \mathrm{~h}$ [22]. Emulsions of unrefined corn oil and spore suspensions of $C$. truncatum (Schw.) Andrus \& Moore also reduced the dew period requirements for maximum infection and mortality of hemp sesbania [Sesbania exaltata (Raf.) Rydb. ex A.W. Hill] from $12 \mathrm{~h}$ to $2 \mathrm{~h}$, and delayed the need for free moisture for $>72 \mathrm{~h}$ [18].

In addition to dew period requirements, the length of time following bioherbicide application and the onset of dew can have negative effects upon infection and control of weeds. For example, dew treatment delays of only $1 \mathrm{~h}$ resulted in a $60 \%$ reduction of hemp sesbania control by $C$. truncatum spores in an aqueous formulation [23]. A dew treatment of $8 \mathrm{~h}$ within two days after inoculation resulted in $95 \%$ control of sicklepod inoculated with spores of Alternaria cassia Jurair \& Khan formulated in $0.02 \%$ nonoxynol (0 - 10 POE) [ $\alpha$-( $p$-nonylphenyl)- $\omega$-hydroxypoly (oxyethylene)] surfactant [24].

Previous research indicated that a strain (NRRL 15,547) of the fungus Colletotrichum coccodes (Wallr.) S. Hughes had bioherbicidal potential for controlling eastern black nightshade (Solanum ptycanthum Dun.) [25] [26], a problematic weed native to the Americas, and commonly found throughout the United States, east of the Rocky Mountains [27]. However, spores of this fungus required a lengthy dew period ( $\geq 16 \mathrm{~h}$ ) in order to germinate, establish infection, and cause disease, and thus it was concluded that this extensive dew period requirement limited the practical use of this pathogen as a mycoherbicide [25]. Various studies of the effects of dew period on the efficacy of commercial and other potential bioherbicides, and methodologies to overcome unrealistically long dew period requirements have been reported [7]. The objective of the 
present investigations was to determine if the dew period requirements of $C$. coccodes to infect and kill eastern black nightshade could be significantly reduced and delayed by formulating fungal spores in an invert emulsion. This research could have important implications since it may also be applicable to certain other fungi that have been considered impractical for use as bioherbicides because of lengthy dew period requirements.

\section{Materials and Methods}

\subsection{Culture and Inoculum Preparation of $C$. coccodes}

Cultures of $C$. coccodes (NRRL 15547) were re-generated from soil-tube [28] stock cultures from the USDA-ARS Southern Weed Science Laboratory Fungal Repository (currently the USDA-ARS Biological Control of Pests Fungal Repository) and grown on half-strength Emerson's yeast-starch agar [Yeast extract $(4.0 \mathrm{~g} / \mathrm{L})$, soluble starch $(15.0$ $\mathrm{g} / \mathrm{L}), \mathrm{Na}_{2} \mathrm{HPO}_{4}(1.0 \mathrm{~g} / \mathrm{L}), \mathrm{MgSO}_{4}(0.5 \mathrm{~g} / \mathrm{L})$, agar $(15.0 \mathrm{~g} / \mathrm{L})$, distilled water $(1000.0 \mathrm{ml})$; $\mathrm{pH}$ adjusted to 6.8] in petri dishes that were inverted on open-mesh wire shelves in an incubator (Precision Scientific Inc., Chicago, IL, USA) at $25^{\circ} \mathrm{C}$. Photoperiods $(12 \mathrm{~h}$ ) were provided by 2, 20-W cool white fluorescent lamps positioned $12 \mathrm{~cm}$ above each shelf to provide $200 \mu \mathrm{E} \cdot \mathrm{m}^{-2} \cdot \mathrm{s}^{-1}$. Spores were harvested by rinsing the cultures with distilled water and filtering debris through 4 layers of cheesecloth. Freshly harvested spores were used as inoculum for all experiments. The spore concentration in test preparations was estimated using hemacytometers. Long-term storage of the fungus was achieved in screw-capped tubes containing sterilized soil, maintained at $4^{\circ} \mathrm{C}$ [28].

The treatments were as follows: 1) untreated; 2$) 0.05 \%(\mathrm{w} / \mathrm{v})$ oxysorbic (20 POE) polyoxyetylene sorbitan mono-oleate surfactant (Tween 80 ); 3 ) invert emulsion control; 4) C. coccodes spores suspended in $0.05 \%$ Tween 80 ; 5) C. coccodes spores suspended in the invert emulsion. The composition of the invert emulsion was identical to that previously described [17] [21]. The oil phase of the invert emulsion consisted of a paraffinic oil (Orchex 797; Exxon Corp., Baytown, TX, USA) (777.5 g. $\mathrm{L}^{-1}$ ), a monoglyceride emulsifier (Myverol 18-99; Eastman Chem. Prod., Inc., Kingsport, TN, USA) (14.5 $\mathrm{g} \cdot \mathrm{L}^{-1}$ ), household paraffin wax (Strohmeyer \& Arpe Co., Inc., Short Hills, NJ, USA) $\left(74.25 \mathrm{~g} \cdot \mathrm{L}^{-1}\right)$, and lanolin $\left(93 \mathrm{~g} \cdot \mathrm{L}^{-1}\right)$. A stable invert emulsion was formed when equal parts of the oil phase and water phase were combined and stirred briskly by hand for 2 -

$3 \mathrm{~min}$. Inoculum densities for all treatments (aqueous or invert emulsion) containing the fungal spores were adjusted to $1.0 \times 10^{6}$ spores $\mathrm{ml}^{-1}$. Spray application rates were approximately $300 \mathrm{~L} \cdot \mathrm{ha}^{-1}$, and were applied using hand-held sprayers (Crown SpraTool, North American Professional Products, Woodstock, IL, USA).

\subsection{Culture of Plants}

Eastern black nightshade seeds were obtained from C.T. Bryson (USDA-ARS, Stoneville, MS, USA). Seeds were surface-sterilized in $0.05 \% \mathrm{NaOCl}$ for $5 \mathrm{~min}$, rinsed with sterile distilled water, and germinated on moistened filter paper in petri dishes. After the seeds germinated $(\sim 48 \mathrm{~h})$, they were planted in a commercial potting mix (Jiffy-mix; Jiffy Products of America, Batavia, IL, USA) contained in peat strips. Each strip 
contained 12 plants. The potting mix was supplemented with a controlled-release (14:14:14, NPK) fertilizer (Osmocote; Grace Sierra Horticultural Products, Milpitas, CA, USA). The plants were placed in sub-irrigated trays mounted on greenhouse benches. Greenhouse temperatures ranged from $25^{\circ} \mathrm{C}$ to $30^{\circ} \mathrm{C}$ with $40-90 \%$ relative humidity $(\mathrm{RH})$. The photoperiod was approximately $14 \mathrm{~h}$, with $1800 \mu \mathrm{E} \cdot \mathrm{m}^{-2} \cdot \mathrm{s}^{-1}$ (PAR) as measured with a light meter (LI-COR, Inc., Lincoln, NE, USA) at midday. Seedlings at the 3 - 4 leaf stage were used in all experiments.

\subsection{Dew Period Duration and Dew Delay Studies}

Following treatments, seedlings were placed either directly on greenhouse benches $(0 \mathrm{~h}$ dew) or in darkened dew chambers (Model I-36 DL; Percival Sci. Ind., Perry, IA, USA) at $25^{\circ} \mathrm{C}, 100 \mathrm{RH}$ for $4,8,12,16,20$, or $24 \mathrm{~h}$, and then placed on greenhouse benches. To study the effect of dew treatment delays, plants were either placed directly in a dew chamber for $16 \mathrm{~h}$ (under conditions as described) or subjected to dew delays of $0,2,4$, $8,12,16,20,24,48$, or $72 \mathrm{~h}$ before being subjected to a $16 \mathrm{~h}$ dew treatment. Plants were monitored at 3-day intervals for disease kinetic studies, and determinations of mortality and dry weight reductions over a 12-day period after treatment. A subjective visual disease severity rating scale (per plant basis) [19] was used to estimate disease progression where $0=$ no disease, $1=1 \%-25 \%$ disease, $2=26 \%-50 \%$ disease, $3=51 \%-75 \%$ disease, $4=76 \%$ - 99\% disease, and $5=$ plant death. Disease ratings $\leq 2.0$ were considered "slight", 2.1 - 3.9 were considered "moderate", and $\geq 4.0$ were considered "severe". Surviving plants were excised at the soil line, oven-dried for $48 \mathrm{~h}$ at $85^{\circ} \mathrm{C}$, weighed, and the percent biomass reduction was determined. Treatments were replicated four times, for a total of 48 individual plants per treatment. The experiment was repeated over time, and data were averaged following Bartlett's test for homogeneity of variance [29]. A randomized complete block experimental design with four replications was utilized. The mean percentage of plant mortalities and biomass reductions were calculated for each treatment, and were subjected to Arcsin transformation. The transformed data were statistically compared using analysis of variance (ANOVA) at the 5\% probability level. Results were back-transformed to the original measurements (percentages) for presentation. Data were analyzed via the PROC MIXED function of SAS v9.3 (SAS Institute, Cary, NC, USA) using a least significant difference of 0.05. In the dew period and disease kinetic studies, best-fit regression analysis was also utilized.

\section{Results}

Dew periods of 4,8 , or 12 h provided 10, 25, and $40 \%$ control of eastern black nightshade plants, respectively, when $C$. coccodes spores were applied in water + Tween 20, but at least $16 \mathrm{~h}$ of dew was required to achieve $~ 95 \%$ mortality of plants. Some mortality and dry weight reductions occurred with $0 \mathrm{~h}$ of dew, which was attributed to the wet conditions of the potting mix (Figure 1(A) \& Figure 1(B)). In contrast, at these same dew period lengths, 95\%, 100\% and 100\% mortality occurred, respectively, when spores were formulated in the invert emulsion. Even with no dew $(0 \mathrm{~h}), 60 \%$ mortality and 


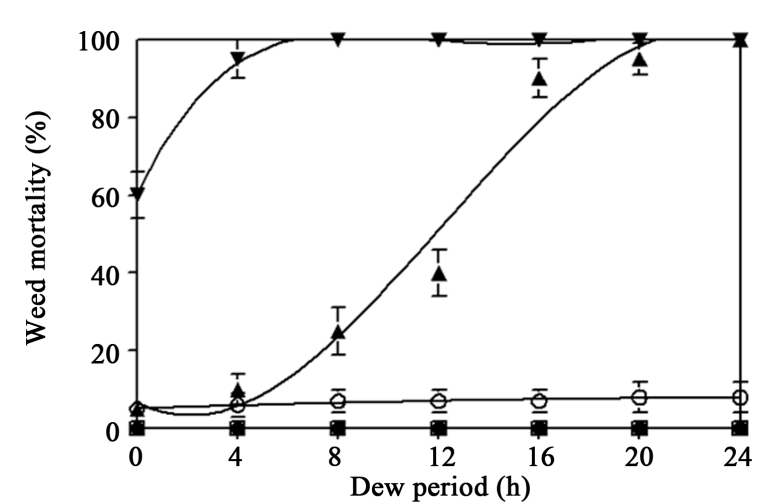

(A)



(B)

Figure 1. Effect of dew period duration on mortality (A) and dry weight reduction (B) of eastern black nightshade treated with $C$. coccodes formulated either in water + Tween $80(0.05 \% \mathrm{w} / \mathrm{v})$ surfactant or an invert emulsion, 12 days after inoculation. Treatments: 1) C. coccodes in water + Tween $80(0.05 \% \mathrm{w} / \mathrm{v})$ surfactant (triangles); 2) C. coccodes in invert emulsion (inverted triangles); invert only control = open circles; 3 ) water + Tween 80 control = solid circles; 4 ) untreated control $=$ open squares. Error bars represent standard error of the mean. The data curves for mortality are best represented by the equations: $\mathrm{Y}=2.90-0.06 \mathrm{X}+.07 \mathrm{X}^{2}-0.01 \mathrm{X}^{3} ; \mathrm{R}^{2}=0.90(C$. coccodes in water + Tween 80$) ; \mathrm{Y}=9.6+7.25 \mathrm{X}-3.09 \mathrm{X}^{2}+0.45 \mathrm{X}^{3} ; \mathrm{R}^{2}=0.98$ (C. coccodes in invert emulsion). The data curves for dry weight reduction are best represented by the equations: $\mathrm{Y}$ $=1.48+0.79 \mathrm{X}-0.09 \mathrm{X}^{2}+0.01 \mathrm{X}^{3} ; \mathrm{R}^{2}=0.86($ C. coccodes in water + Tween 80$) ; \mathrm{Y}=14.8+4.85 \mathrm{X}$ $-2.29 \mathrm{X}^{2}+0.40 \mathrm{X}^{3} ; \mathrm{R}^{2}=0.98$ (C. coccodes in invert emulsion).

$70 \%$ dry weight reductions of plants was achieved when the fungus was formulated in the invert emulsion $72 \mathrm{~h}$ after inoculation (Figure 1(A) \& Figure 1(B). Minimal (10\% $15 \%)$ mortality and dry weight reductions were observed on plants treated with the invert formulation alone.

In the delayed dew studies, a $2 \mathrm{~h}$ dew delay did not significantly reduce weed control or dry weight reductions when plants were inoculated with $C$. coccodes in either the aqueous or in the invert emulsion treatment (Figure 2(A) \& Figure 2(B). However, when dew was delayed for 4,8 , or $12 \mathrm{~h}$, only $60 \%, 50 \%$, and $25 \%$ control, respectively, of eastern black nightshade plants receiving the aqueous spore treatment was observed. In contrast, $95 \%, 90 \%$, and $90 \%$ weed mortality occurred after the same dew delays to plants receiving the fungus-invert emulsion treatments (Figure $2(\mathrm{~A})$ ). Dry weight reductions followed similar trends (Figure 2(B)). 



(B)

Figure 2. Effects of delayed dew period on mortality (A) and dry weight reduction (B) of eastern black nightshade treated with $C$. coccodes formulated either in water + Tween $80(0.05 \% \mathrm{w} / \mathrm{v})$ surfactant or an invert emulsion, 12 days after inoculation. Treatments: 1$)$ C coccodes in water + Tween $80(0.05 \% \mathrm{w} / \mathrm{v})$ surfactant (gray bars); 2) C. coccodes in invert emulsion (white bars); water + Tween 80 control (red bars); 3) invert only control (blue bars); 4) untreated control (green bars). All plants were subjected to a $16-\mathrm{h}$ dew period immediately, or after each delay time, and mortality and dry weight reductions were determined 12 days after inoculation. Error bars denoted with the same letter are not significant at $p=0.05$ according to FLSD.

In the disease kinetic studies, after 3 days, plants that received the aqueous spore treatment were only slightly infected (disease rating 2.0), while plants that were treated with the fungal-invert emulsion treatment were severely infected (disease rating 4.5) after this time period (Figure 3). After 6 days, plants receiving the aqueous fungal treatment were still only moderately infected (disease rating 2.9 ), while $100 \%$ mortality occurred to plants treated with the fungus-invert formulation; 9 days were required before severe (disease rating 4.8) levels of disease were achieved on plants receiving the aqueous fungal treatment (Figure 3).

\section{Discussion}

C. coccodes NRRL 15547 is highly virulent against eastern black nightshade, provided that dew conditions are favorable to promote the infection process. The minimum dew period to achieve $95 \%$ - 100\% mortality was 16 - $24 \mathrm{~h}$ for C. coccodes spores when formulated in the surfactant only (Figure $1(\mathrm{~A})$ ). These dew period requirements are similar to those reported for several other bioherbicides and potential bioherbicides including: Colletotrichum gloeosporioides f. sp. aeschynomene (Penz.) Penz. \& Sacc. for northern jointvech [Aeschynomene virginica (L.) B.S.P.] control [30], Fusarium lateritium Nees ex Fr. for velvetleaf (Abutilon theophrasti) Medic. control [31], C. gloeosporioides f. sp. malvae (Penz.) Penz. \& Sacc. for round-leaved mallow (Malva pusilla L.) 


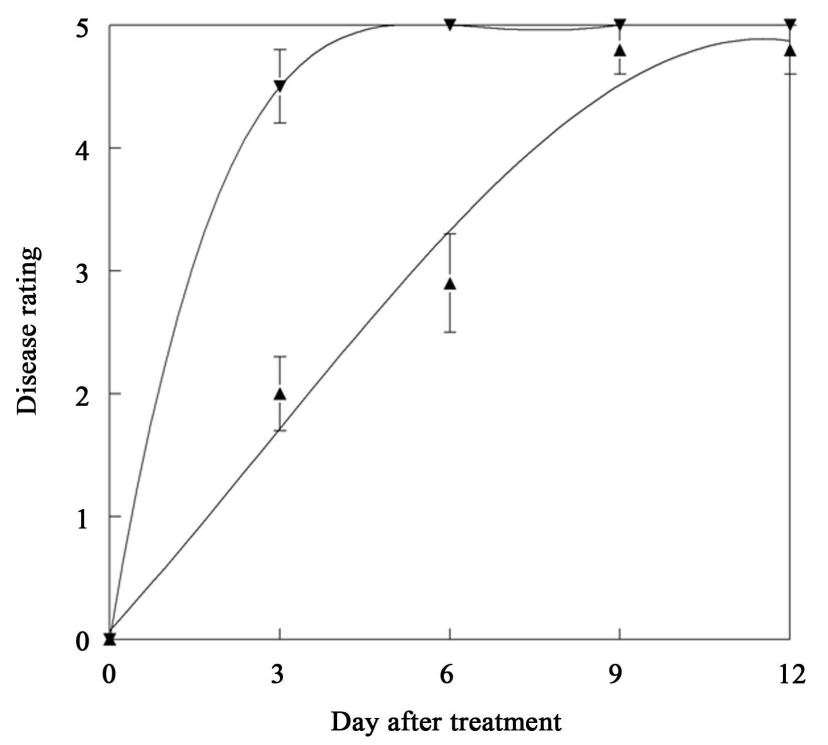

Figure 3. Disease kinetic studies of the bioherbicidal efficacy of $C$. coccodes formulated either in water + Tween $80(0.05 \% \mathrm{w} / \mathrm{v})$ surfactant or an invert emulsion, 12 days after inoculation. Treatments: 1) C. coccodes in water + Tween $80(0.05 \% \mathrm{w} / \mathrm{v})$ surfactant (triangles); 2) C. coccodes in invert emulsion (inverted triangles). Error bars represent FLSD at $p=0.05$. The data curves for disease progression are best represented by the equations: $\mathrm{Y}=0.07+0.51 \mathrm{X}+0.02 \mathrm{X}^{2}-$ $0.01 \mathrm{X}^{3}, \mathrm{R}^{2}=0.97(C$. coccodes in water + Tween 80 surfactant $) ; \mathrm{Y}=2.50+2.81 \mathrm{X}-0.57 \mathrm{X}^{2}+$ $0.05 \mathrm{X}^{3}, \mathrm{R}^{2}=0.98$ (C. coccodes in invert emulsion).

control [32], Exserohilum monoceras (Drechs.) K.J. Leonard \& E.G. Suggs for jungle rice [Echinochloa colona (L.) Link.] control [33], Phomopsis convolvulus Ormeno for field bindweed (Convolvulus arvensis L.) control [34], and Phomopsis amaranthicola Rosskopf and Microsphaeropsis amaranthi Ell. \& Barth., as bioherbicides for several weedy Amaranthus species [35].

Although it has been suggested that dew period requirements $\geq 16 \mathrm{~h}$ could limit the practical use of fungi as biological control agents for weeds [3], through innovative use of formulations, such as invert emulsions, it may be possible to render such bioherbicidal fungi more useful for controlling their target weeds. Minimal (5\% - 15\%) mortality and dry weight reductions were observed on eastern black nightshade plants treated with the invert formulation alone, which could have facilitated fungal entry and infection. This invert emulsion can also cause injury to some other species of weeds [36] and caution should be taken to avoid potential damage to crops associated with the target weed. These results provide further evidence that bioherbicidal efficacy can be improved using bio-based formulation approaches. Further research is needed to test this formulation for control of eastern black nightshade under field conditions.

\section{Conclusion}

The unpredictability of the occurrence of dew (or other free-moisture events) is a major factor influencing the efficacy of bioherbicidal fungi. Thus, the ability to mitigate environmental factors, such as requirements for lengthy dew periods, that restrict or limit a 
bioherbicidal microorganism's efficacy, can significantly improve their bioherbicidal potential. This research could have important implications since it may also be applicable to certain other fungi that have been considered impractical for use as bioherbicides because of lengthy dew period requirements.

\section{References}

[1] Charudattan, R. and Walker, H.L. (1982) Biological Control of Weeds with Plant Pathogens. John Wiley, New York.

[2] Hoagland, R.E. (1990) Microbes and Microbial Products as Herbicides-An Overview. In: Hoagland, R.E., Ed., Microbes and Microbial Products as Herbicides, American Chemical Society Symposium Series No. 439, ACS Books, Washington DC, 2-52.

[3] TeBeest, D.O. (1991) Microbial Control of Weeds. Chapman and Hall, New York. http://dx.doi.org/10.1007/978-1-4615-9680-6

[4] Rosskopf, E.N., Charudattan, R. and Kadir, J.B. (1999) Use of Plant Pathogens in Weed Control. In: Katar, E.H., Ed., Handbook of Weed Control, Academic Press, New York, 891-911. http://dx.doi.org/10.1016/b978-012257305-7/50082-5

[5] Charudattan, R. (2005) Ecological, Practical, and Political Inputs into Selection of Weed Targets: What Makes a Good Biological Control Target? Biological Control, 35, 183-196. http://dx.doi.org/10.1016/j.biocontrol.2005.07.009

[6] Hallett, S.G. (2005) Where Are the Bioherbicides? Weed Science, 53, 404-415. http://dx.doi.org/10.1614/WS-04-157R2

[7] Weaver, M.A., Lyn, M.E., Boyette, C.D. and Hoagland, R.E. (2007) Bioherbicides for Weed Control. In: Updhyaya, M.K. and Blackshaw, R.E., Eds., Non-Chemical Weed Management, CABI, International, Cambridge, MA, 93-110. http://dx.doi.org/10.1079/9781845932909.0093

[8] Bailey K.L. (2014) The Bioherbicide Approach to Weed Control Using Plant Pathogens. In: Abrol, D.P., Ed., Integrated Pest Management. Current Concepts and Ecological Perspectives, Elsevier, San Diego, 245-266. http://dx.doi.org/10.1016/B978-0-12-398529-3.00014-2

[9] Duke S.O., Scheffler, B.E., Boyette, C.D. and Dayan, F.E. (2015) Biotechnology in Weed Control. In: Kirk-Othmer Encyclopedia of Chemical Technology, John Wiley \& Sons, New York, 1-25. http://dx.doi.org/10.1002/0471238961.herbduke.a01.pub2

[10] Cordeau, S., Triolet, M., Waymon, S., Steinberg, C. and Guillemin, J.P. (2016) Bioherbicides: Dead in Water? Crop Protection, 87, 44-49. http://dx.doi.org/10.1016/j.cropro.2016.04.016

[11] Agrios, GN, (2004) Plant Pathology. 5th Edition, Academic Press, San Diego.

[12] Auld, B.A., Hethering, S.D. and Smith, H.E. (2003) Advances in Bioherbicide Formulation. Weed Biology and Management, 3, 61-67. http://dx.doi.org/10.1046/j.1445-6664.2003.00086.x

[13] Yang, X.B. and TeBeest, D.O. (1993) Epidemiological Mechanisms of Mycoherbicide Effectiveness. Phytopathology, 83, 891-893.

[14] Boyette, C.D. and Hoagland, R.E. (2013) Adjuvant and Refined Corn Oil Formulation Effects on Conidial Germination, Appressorial Formation and Virulence of the Bioherbicide, Colletotrichum truncatum. Plant Pathology Journal, 12, 50-60. http://dx.doi.org/10.3923/ppj.2013.50.60

[15] Quimby Jr., P.C., Fulgham, F.E., Boyette, C.D. and Connick Jr., W.J. (1989) An Invert Emulsion Replaces Dew in Biocontrol of Sicklepod-A Preliminary Study. In: Hovde, D. 
and Beestman, G.B., Eds., Pesticide Formulations and Application Systems, American Society for Testing Materials, West Conshohocken, PA, 267-270.

http://dx.doi.org/10.1520/stp26463s

[16] Auld, B.A. (1993) Vegetable Oil Suspension Emulsions Reduce Dew Dependence of a Mycoherbicide. Crop Protection, 12, 477-479. http://dx.doi.org/10.1016/0261-2194(93)90011-7

[17] Boyette, C.D., Quimby Jr., P.C., Bryson, C.T., Egley, G.H. and Fulgham, F.E. (1993) Biological Control of Hemp Sesbania (Sesbania exaltata) Under Field Conditions with Colletotrichum truncatum Formulated in an Invert Emulsion. Weed Science, 41, 497-500.

[18] Boyette, C.D. (1994) Unrefined Corn Oil Improves the Mycoherbicidal Activity of Colletotrichum truncatum for Hemp Sesbania (Sesbania exaltata) Control. Weed Technology, 8, 526-528.

[19] Sandrin, T.R., TeBeest, D.O. and Weidemann, G.J. (2003) Soybean and Sunflower Oils Increase the Infectivity of Colletotrichum gloeosporioides $\mathrm{f}$. sp. aeschynomene to Northern Jointvetch. Biological Control, 26, 244-252. http://dx.doi.org/10.1016/S1049-9644(02)00156-1

[20] Boyette, C.D., Hoagland, R.E. and Weaver, M.A. (2007) Effect of Row Spacing on Biological Control of Sicklepod (Senna obtusifolia) with Colletotrichum gloeosporioides. Biocontrol Science and Technology, 17, 957-967. http://dx.doi.org/10.1080/09583150701553157

[21] Boyette, C.D., Gealy, D., Hoagland, R.E., Vaughn, K.C. and Bowling, A.J. (2011) Hemp Sesbania (Sesbania exaltata) Control in Rice (Oryza sativa) with the Bioherbicidal Fungus Colletotrichum gloeosporioides f. sp. aeschynomene Formulated in an Invert Emulsion. Biocontrol Science and Technology, 21, 1399-1407. http://dx.doi.org/10.1080/09583157.2011.625398

[22] Boyette, C.D. (2006) Adjuvants Enhance the Biological Control Potential of an Isolate of Colletotrichum gloeosporioides for Biological Control of Sicklepod (Senna obtusifolia). Biocontrol Science and Technology, 16, 1057-1066. http://dx.doi.org/10.1080/09583150600828692

[23] Boyette, C.D., Bryson, C.T., Hoagland, R.E. and Weaver, M.A. (2012) Effects of Simulated Rainfall on Disease Development and Weed Control of the Bioherbicidal Fungi Alternaria cassiae and Colletotrichum truncatum. Weed Technology, 26, 117-121. http://dx.doi.org/10.1614/WT-D-10-00127.1

[24] Walker, H.L. and Boyette, C.D. (1986) Influence of Sequential Dew Periods on Biocontrol of Sicklepod (Cassia obtusifolia) by Alternaria cassiae. Plant Disease, 45, 962-963. http://dx.doi.org/10.1094/PD-70-962

[25] Andersen, R.N. and Walker, H.L. (1985) Colletotrichum coccodes. A Pathogen of Eastern Black Nightshade (Solanum ptycanthum). Weed Science, 33, 902-905.

[26] Andersen, R.N. and Walker, H.L. (1987) Control of Eastern Black Nightshade with a Fungal Pathogen. U.S. Patent No. 4715881.

[27] Bryson, C.T. and DeFelice, M.S. (2009) Weeds of the South. University of Georgia Press, Athens, GA, $468 \mathrm{p}$.

[28] Bakerspigel, A. (1953) Soils as a Storage Medium for Fungi. Mycologia, 45, 596-604.

[29] Steel, R.G.D., Torrey, J.H. and Dickeys, D.A. (1997) Multiple Comparisons. Principles and Procedures of Statistics-A Biometrical Approach. McGraw-Hill, New York, 365 p.

[30] TeBeest, D.O., Templeton, G.E. and Smith Jr., R.J. (1978) Temperature and Moisture Requirements for Development of Anthracnose on Northern Jointvetch. Phytopathology, 68, 389-393. http://dx.doi.org/10.1094/Phyto-68-389 
[31] Boyette, C.D. and Walker, H.L. (1985) Factors Influencing Biocontrol of Velvetleaf (Abutilon theophrasti) and Prickly Sida (Sida spinosa) with Fusarium lateritium. Weed Science, 33, 209-211.

[32] Makowski, R.M.D. (1993) Effect of Inoculum Concentration, Temperature, Dew Period and Plant Growth Stage on Disease of Round-Leaved Mallow and Velvetleaf by Colletotrichum gloeosporioides f. sp. malvae. Phytopathology, 83, 1229-1234. http://dx.doi.org/10.1094/Phyto-83-1229

[33] Zhang, W. and Watson, A.K. (1997) Effect of Dew Period and Temperature on the Ability of Exserohilum monoceras to Cause Seedling Mortality of Echinochloa Species. Plant Disease, 81, 629-634. http://dx.doi.org/10.1094/PDIS.1997.81.6.629

[34] Morin, L., Watson, A.K. and Reeleder, R.D. (1990) Effect of Dew, Inoculum Density and Spray Additives on Infection of Field Bindweed by Phomopsis convolvulus. Canadian Journal of Plant Pathology, 12, 48-56. http://dx.doi.org/10.1080/07060669009501042

[35] Oritz-Ribbing, L. and Williams, M.M. (2006) Potential of Phomopsis amaranthicola and Microsphaeropsis amaranthi, as Bioherbicides for Several Weedy Amaranthus Species. Crop Protection, 25, 39-46. http://dx.doi.org/10.1016/j.cropro.2005.03.021

[36] Rosskopf, E.N., Yandoc, C.B., Charudattan, R. and DeValerio, J.T. (2005) Influence of Epidemiological Factors on the Bioherbicidal Efficacy of Phomopsis amaranthicola on Amaranthus hybridus. Plant Disease, 89, 1295-1300. http://dx.doi.org/10.1094/PD-89-1295

Submit or recommend next manuscript to SCIRP and we will provide best service for you:

Accepting pre-submission inquiries through Email, Facebook, LinkedIn, Twitter, etc. A wide selection of journals (inclusive of 9 subjects, more than 200 journals)

Providing 24-hour high-quality service

User-friendly online submission system

Fair and swift peer-review system

Efficient typesetting and proofreading procedure

Display of the result of downloads and visits, as well as the number of cited articles Maximum dissemination of your research work

Submit your manuscript at: http://papersubmission.scirp.org/

Or contact ajps@scirp.org 